\title{
Adsorptive Removal of Textile Dye Direct Blue 9 from Aqueous Solution by Nano-Sized Polymers: Kinetic and Thermodynamic Studies
}

\author{
Aslı Göçenoğlu Sarıkaya* \\ Faculty of Science and Art, Bursa Uludag University, Görükle Campus, Bursa, Turkey
}

Received: 29 January 2019

Accepted: 27 July 2019

\begin{abstract}
In this study, polymeric nanoparticles were used as an adsorbent to remove the textile dye Direct Blue 9 (DB9) from an aqueous solution. Adsorption capacity of the polymeric nanoparticles were determined in various conditions such as $\mathrm{pH}$, temperature, and dye concentration. Kinetic parameters were also calculated. Optimum initial $\mathrm{pH}$, temperature and equilibrium time were determined as 6.0, $318 \mathrm{~K}$ and 90 minutes, respectively. The maximum adsorption capacity of adsorbent and percentage removal of DB9 were detected as $15.49 \mathrm{mg} / \mathrm{g}$ and $98.15 \%$, respectively. To clarify the nature of the adsorption process isotherm, thermodynamic and kinetic studies were also performed. The adsorption process obeys the Langmuir isotherm model and pseudo-second order model.
\end{abstract}

Keywords: Direct Blue 9, adsorption; nanopolymers, removal, textile dye

\section{Introduction}

Organic dyes, which include azo dyes or complex aromatic structure [1], are widely used in the textile industry [2], pulp and paper manufacturing, printing and leather treatment [3]. However, these industrial wastes are hazardous for living organisms, especially in aquatic forms [4]. Many of them are classified as carcinogenic and toxic [5]. In general, they are biologically non-degradable, and stable to heat, light and oxidizing agents $[1,6]$. Due to the inert properties of dyes, traditional treatment technologies of industrial wastewater have been improved. Coagulation/ flocculation [7-9], membrane filtration [10, 11],

*e-mail: agocenoglu@uludag.edu.tr electrochemical methods [12, 13], biodegradation [14], $\mathrm{TiO}_{2}$ photo-catalysis $[15,16]$, ion exchange $[17,18]$ and adsorption $[19,20]$ processes are widely used to remove dyes from wastewater.

Because of the high removal efficiency of dye removal, adsorption is one of the most commonly used techniques to treat wastewater [21]. Adsorption gives some advantages to researchers and companies since the operation is cheap, simple and easy, with a wide field of suitable and available adsorbents allowing for adsorbent regeneration and reuse [22-25].

Durability, preservability as a long time and stability of nanopolymers have created the much-applied potential for using these structures in many areas. Activated carbon [26, 27], 'low cost adsorbents' such as agricultural solid wastes [28], biomass solid wastebased activated carbon [29], inorganic materials like clay minerals [30], siliceous materials [31], bentonites 
or zeolites [32, 33], biosorbents, microbial biomass [34$36]$ and polymeric materials [20,37] are widely used as adsorbents. Polymeric materials, especially nano-sized polymers, are widely used as adsorbents due to their size-dependent physical and chemical properties [38].

Textile dyes are classified due to their chromophore or chemical structures such as anthraquinone, ethane, azo, and phthalocyanine. The most common one is azo dye, which is used in the textile and paper industries. Azo dyes include azo bond ( $\mathrm{R}-\mathrm{N}=\mathrm{N}-\mathrm{R}$ ') and one or more aromatic rings. In general, azo dyes have mutagenic, toxic, and carcinogenic structures, thus these dyes not only affect human as carcinogens and mutagens but also affect aquatic environments. These dyes are stable and non-degradable by biological or chemical processes. Direct Blue dyes are classified into three class as mono-, di-, and tri-azo dyes [38]. Direct Blue 9 (DB9) is mainly used as dyestuff in textile industries, and the removal of these dyes is important. Various methods such as coagulation/flocculation, ion exchange, electrochemical treatment, chemical oxidation, biological treatment, and adsorption are used to remove azo dyes from wastewater [39].

This study focused on removing the toxic textile dye Direct Blue 9 (DB9) from aqueous solutions and representing the usability of poly(2-hydroxyethyl methacrylate) [poly(HEMA)] nano-sized polymers as an adsorbent. Poly(HEMA) was produced by the emulsion polymerization method and then characterized by infrared spectroscopy (IR) and scanning electron microscopy (SEM). Batch adsorption experiments were performed under various operating conditions such as $\mathrm{pH}$, contact time and temperature. Adsorption isotherms and kinetic values were determined. Also, reusability of the polymer was discussed.

\section{Experimental}

\section{Materials}

Direct Blue 9 (DB9, synonym; Sirius Blue K-CFN, C.I. 24155), hydroxyethyl methacrylate (HEMA; $\geq 99 \%$ ), polyvinyl alcohol (PVA; MW: 130 000) and ethylene glycol dimethacrylate (EGDMA; 98\%) were obtained from Aldrich (Steinheim, Germany). Sodium dodecyl sulfate (SDS; $\geq 98.5 \%$ ) was purchased from Sigma (Steinheim, Germany). All other chemicals were analytical grade. The chemical structure of DB9 is given in Fig. 1.

\section{Synthesis of Poly(HEMA) Nanopolymers}

Poly(HEMA) nanopolymers were synthesized by the previously given emulsion polymerization procedure [38]. First of all, in the first aqueous phase PVA, SDS and $\mathrm{NaHCO}_{3}$ were dissolved in distilled water. In the second aqueous phase, PVA and SDS were dissolved in distilled water in other erlenmayer. In the oil phase,

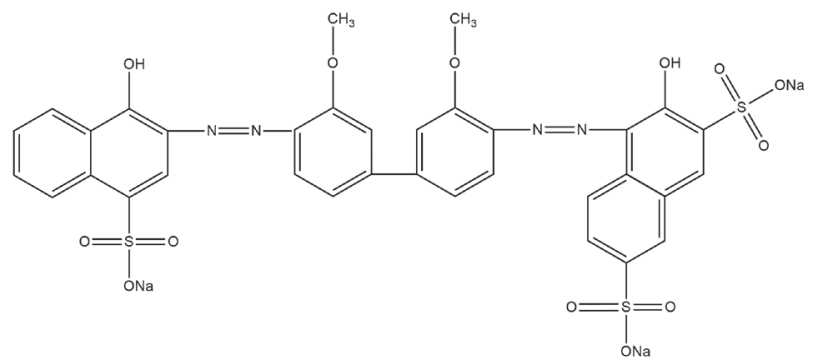

Fig. 1. Chemical structure of DB9.

HEMA was mixed with EGDMA and added to the first aqueous phase. The mixture was homogenized at $30000 \mathrm{rpm}$ (ISOLAB Homogenizer, 'Heavy Duty') for 10 minutes. The mixture was added to the second aqueous phase, and $\mathrm{NaHSO}_{3}$ and $\left(\mathrm{NH}_{4}\right)_{2} \mathrm{~S}_{2} \mathrm{O}_{8}$ were added. The polymerization was carried out at $40^{\circ} \mathrm{C}$ for $6 \mathrm{~h}$. At the end of the polymerization, to remove the unreacted monomers, the polymers were washed with ethanol and water several times. Additionally, polymers were washed with distilled water and stored in water.

\section{Characterization Studies}

FT-IR analysis was performed on a Perkin Elmer Spectrum BX FTIR System. The morphology of the nanopolymers was determined by scanning electron microscope (SEM) (SEM2-Quanta 250FEG) in "Izmir Institute of Technology, Center for Materials Research",

\section{Batch Adsorption Experiments}

Initially, experiments to comment on the effect of $\mathrm{pH}$ on dye adsorption capacity and different $\mathrm{pH}$ values were carried out. The tested initial $\mathrm{pH}$ values (3.0 to 8.0) were prepared with acetate $(0.1 \mathrm{M}$ $\left.\mathrm{NaCH}_{3} \mathrm{COO} / \mathrm{CH}_{3} \mathrm{COOH}\right)$ or phosphate $\left(0.1 \mathrm{M} \mathrm{NaH}_{2} \mathrm{PO}_{4} /\right.$ $\mathrm{Na}_{2} \mathrm{HPO}_{4}$ ) buffers. The dye concentration of these solutions was $30 \mathrm{mg} / \mathrm{L}$. Suspensions were stirred at $25^{\circ} \mathrm{C}$ for $3 \mathrm{~h}$ in a heated incubator $(125 \mathrm{rpm})$.

To determine the optimum dye concentration, the suspensions were prepared by adding poly(HEMA) (1 $\mathrm{mg})$ to $1 \mathrm{~mL}$ DB9 solutions (1.0 to $50.0 \mathrm{mg} / \mathrm{L}$ ) at optimum $\mathrm{pH}$. The suspensions were placed in a heated incubator at $25^{\circ} \mathrm{C}$ under stirring at $125 \mathrm{rpm}$. The amount of dye adsorbed $\left(q_{e}\right)$ and percentage removal $(\% R)$ of DB9 were calculated using Eqs. (1) and (2), respectively:

$$
\begin{gathered}
q_{e}=\frac{\left(C_{0}-C_{e}\right) V}{m} \\
\% \text { Removal }=\frac{\left(C_{0}-C_{e}\right)}{C_{0}} \times 100
\end{gathered}
$$

...where $q_{e}$ is the amount of dye in $\mathrm{mg}$ per gram of adsorbent, and $C_{0}$ and $C_{e}$ are initial and final 
concentrations of dye $(\mathrm{mg} / \mathrm{L})$, respectively. $V$ is the volume of the dye solution $(\mathrm{mL})$ and $m$ is the mass of the adsorbent (g).

\section{Adsorption Isotherms}

The Langmuir sorption isotherm is applied to equilibrium sorption assuming monolayer sorption onto a surface with a limited number of identical binding sites. The Langmuir equation (Eq. 3) is written as [38]:

$$
\frac{C_{e}}{q_{e}}=\frac{1}{Q_{L} K_{L}}+\frac{C_{e}}{Q_{L}}
$$

...where $K_{L}$ is Langmuir constant $(\mathrm{L} / \mathrm{mg}), Q_{L}$ is the maximum adsorption at monolayer coverage $(\mathrm{mg} / \mathrm{g})$, $q_{e}$ is dye concentration at equilibrium onto adsorbent $(\mathrm{mg} / \mathrm{g})$ and $C_{e}$ is dye concentration at equilibrium in solution $(\mathrm{mg} / \mathrm{L})$.

The Freundlich sorption isotherm equation for heterogeneous surface energy systems is given by Eq. 4 [38]:

$$
\ln q_{e}=\ln K_{F}+\frac{1}{n} \ln C_{e}
$$

...where $q_{e}$ is dye concentration at equilibrium onto adsorbent $(\mathrm{mg} / \mathrm{g})$ and $C_{e}$ is dye concentration at equilibrium in solution $(\mathrm{mg} / \mathrm{L}) . K_{F}$ and $n$ are Freundlich constants, determined from the plot of $\ln q_{e}$ versus $\ln C_{e}$. The parameters $\mathrm{K}_{\mathrm{F}}$ and $1 / n$ correlate with sorption capacity and the sorption intensity of the system. The magnitude of the term $(1 / n)$ gives evidence to the availability of the sorbent/adsorbate systems [40].

The Sips sorption isotherm equation was given in Eq. 5. This equation was derived from the limiting behavior of Langmuir and Freundlich isotherms [41].

$$
\frac{1}{q_{e}}=\frac{1}{Q_{\max } K_{s}}\left(\frac{1}{C_{e}}\right)^{1 / n}+\frac{1}{Q_{\max }}
$$

...where $q_{e}$ is dye concentration at equilibrium onto adsorbent $(\mathrm{mg} / \mathrm{g})$ and $C_{e}$ is dye concentration at equilibrium in solution $(\mathrm{mg} / \mathrm{L}) . K_{s}$ is Sips constant $(\mathrm{L} / \mathrm{mg})$ and $Q_{\max }$ is maximum adsorption capacity (mg/g).

\section{Recyclability of the Adsorbent}

The recyclability of the adsorbent was performed by repeated adsorption/desorption cycles using the same adsorbent in the same dye solution at five times. As a desorption agent sodium acetate buffer was used. A constant dosage of polymer (1 $\mathrm{mg})$ was placed in $5 \mathrm{~mL}$ dye solution $(50 \mathrm{mg} / \mathrm{L})$ and kept in contact for $3 \mathrm{~h}$. For each cycle, the adsorption capacity was calculated.

\section{Results and Discussion}

\section{Characterization of the Poly(HEMA)}

The FTIR spectra of before and after adsorption from a range of $600-4000 \mathrm{~cm}^{-1}$ is given in Fig. 2. The bands observed at about $3320 \mathrm{~cm}^{-1}$ could be assigned $\mathrm{O}-\mathrm{H}$ stretching vibration. The bands at $2949 \mathrm{~cm}^{-1}$ shifts to $2955 \mathrm{~cm}^{-1}$ representing $\mathrm{C}-\mathrm{H}$ stretching of $\mathrm{CH}_{3}$. The strong band of $\mathrm{C}=\mathrm{O}$ and $\mathrm{C}-\mathrm{O}$ stretching vibration peaks are observed at 1716 and $1240 \mathrm{~cm}^{-1}$, respectively.

To determine the surface texture and morphology of the adsorbent, scanning electron microscopy (SEM) images were taken before and after adsorption of DB9. The results obviously show that the polymers are spherical and in nano-size with smooth surface. As seen in Fig. 3, the adsorbent has homogeneity, which is supposed to be the active site for DB9 binding. SEM images also revealed that the surface of polymeric adsorbent is flattened after DB9 adsorption.

\section{Effect of $\mathrm{pH}$ on Dye Adsorption}

The textile dyes have different aromatic rings and functional groups (such as nitro, azo or metal) [1, 42]. The $\mathrm{pH}$ of a dye solution is an important effecting factor for adsorption [36, 43]. The ionization of the adsorptive molecule and adsorbent can effectively
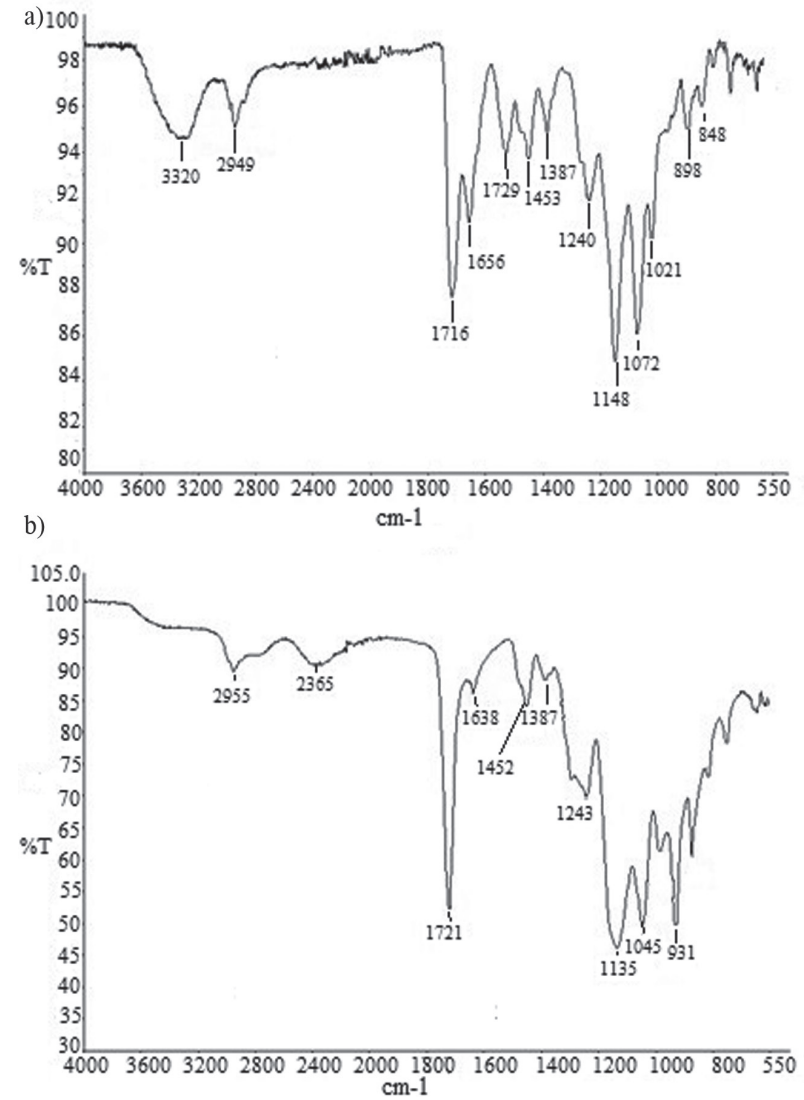

Fig. 2. FT-IR spectrum of poly(HEMA) a) before and b) after adsorption of DB9. 


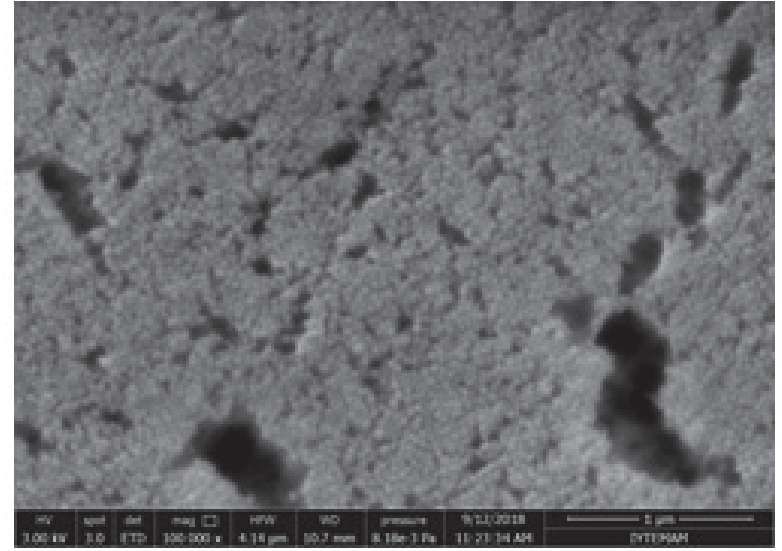

a)

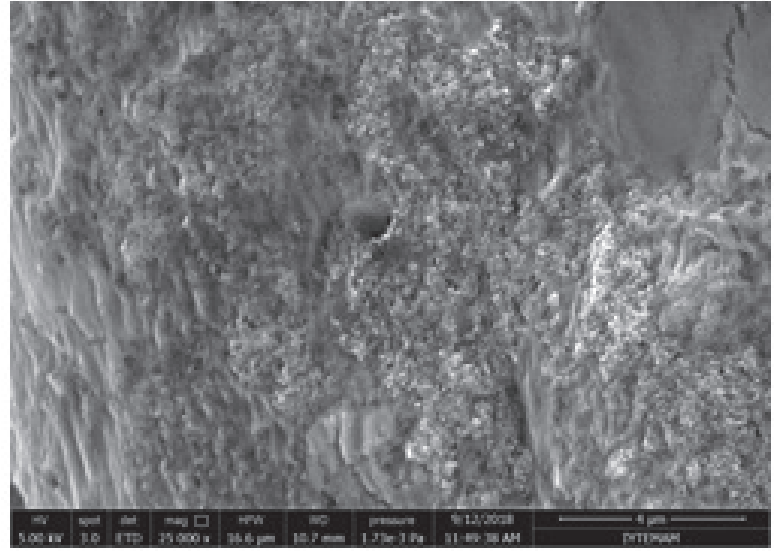

b)

Fig. 3. SEM images of poly(HEMA) a) before and b) after adsorption of DB9.

change by the variation of the $\mathrm{pH}$ solution, hence the dye adsorption is dependent on the solution $\mathrm{pH}[44,45]$. Fig. 4 shows the effect of $\mathrm{pH}$ on adsorption of dye onto the polymer. The maximum adsorption and removal of dye were observed at $\mathrm{pH}$ 6.0. The adsorption capacities of poly(HEMA) increased with $\mathrm{pH}$ until the $\mathrm{pH}$ reached 6.0 , and then the adsorption capacities decreased with increasing $\mathrm{pH}$. The maximum adsorption capacity was determined at $\mathrm{pH}$ 6.0. However, the ionizable groups of dye and poly(HEMA) (hydroxyl groups) are responsible from the electrostatic interactions and hydrogen bonds between dye and polymer.

\section{Effect of Initial Dye concentration and Contact Time on Dye Adsorption}

To determine the optimum dye concentration, the DB9 solutions ranging from 1.0 to $50.0 \mathrm{mg} / \mathrm{L}$ were studied with an amount of $1 \mathrm{mg}$ poly(HEMA) and $1 \mathrm{~mL}$ dye solution at optimum $\mathrm{pH}$ at $298 \mathrm{~K}$. With an increase in the initial DB9 concentration from 1.0 to $50.0 \mathrm{mg} / \mathrm{L}$, the adsorption capacity $\left(q_{e}\right)$ and percentage removal $(\% R)$ at equilibrium increased from $4.07 \mathrm{mg} / \mathrm{g}$ to $22.54 \mathrm{mg} / \mathrm{g}$, and $37.37 \%$ to $98.86 \%$ at $298 \mathrm{~K}$, respectively. The results were given in Fig. 5.

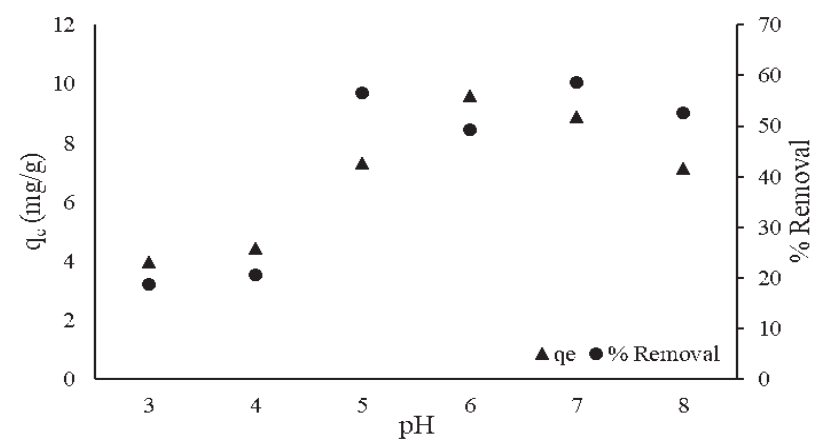

Fig. 4. Effect of $\mathrm{pH}$ for adsorption capacity $\left(q_{e}\right)$ and percentage removal $(\% R)$ of DB9 onto poly(HEMA).
The effect of contact time on the adsorption capacities of dye onto poly(HEMA) and removal percentage at 277, 298 and $318 \mathrm{~K}$ are shown in Fig. 6a) and Fig. 6b), respectively. The adsorbed amounts of dyes increased with an increase in both contact time and temperature. Adsorption process was completed within $90 \mathrm{~min}$ and no remarkable changes were observed until $180 \mathrm{~min}$. Lots of free adsorbent sites are available for adsorption and thus dye molecules can affectively adsorb onto these sites, rapidly increasing the temperature. $82.30 \%, \quad 94.07 \%$ and $98.15 \%$ DB9 removal takes place at 277, 298 and $318 \mathrm{~K}$ in 1 $80 \mathrm{~min}$, respectively. The adsorption capacities of the poly(HEMA) are 12.98, 14.84 and $15.49 \mathrm{mg} / \mathrm{g}$ at 277 , 298 and $318 \mathrm{~K}$, respectively.

\section{Effect of Adsorbent Dosage and Agitation Rate}

To determine the effect of adsorbent dosage for adsorption capacity and percentage removal of DB9 from an aqueous solution, the different adsorbent values ranging from $0.5 \mathrm{mg}$ to $8 \mathrm{mg}$ were used in the adsorption process. The initial concentration of DB9 was $25 \mathrm{mg} / \mathrm{L}$ and the contact time was 180 minutes at

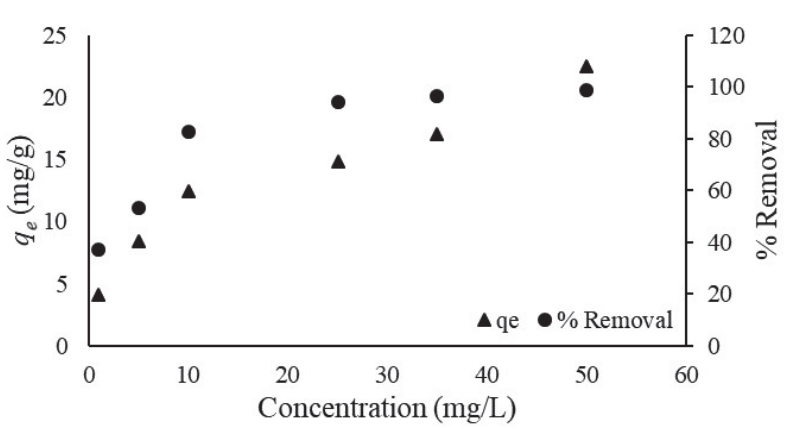

Fig. 5. Effect of initial DB9 concentration for adsorption capacity $\left(q_{e}\right)$ and percentage removal $(\% R)$ of DB9 onto poly(HEMA). 

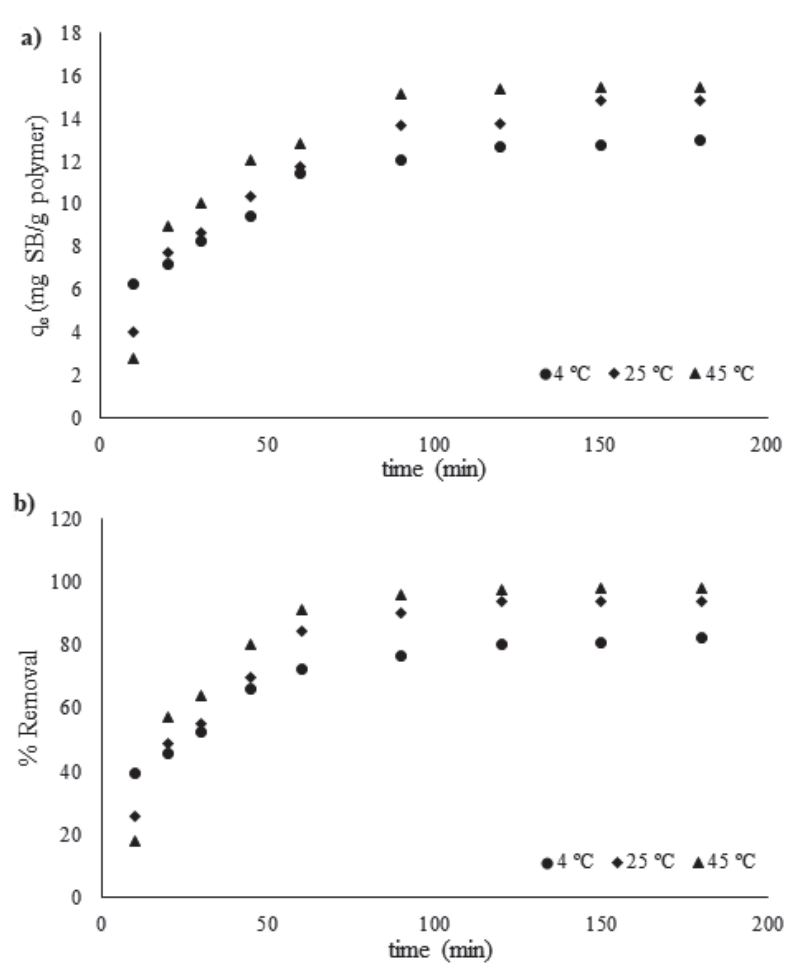

Fig. 6. Effect of contact time and temperature onto a) adsorption capacity $\left(q_{e}\right)$ and b) percentage removal $(\% R)$ for adsorption of DB9 onto poly(HEMA).

298 K. The results were given in Fig. 7. With increasing the amount of adsorbent from $0.5 \mathrm{mg}$ to $8 \mathrm{mg}, q_{e}$ and percentage $R$ increased from $3.85 \mathrm{mg} / \mathrm{g}$ to $28.63 \mathrm{mg} / \mathrm{g}$, and from $86.43 \%$ to $99.70 \%$, respectively. Increase in the percentage $R$ and $q_{e}$ with adsorbent dosage can be based on increased adsorbent surface area and adsorption sites.

To determine the effect of agitation speed for adsorption of DB9 in the range of $75-150 \mathrm{rpm}$, agitation rates were investigated during the adsorption process. The adsorbent dosage was $1 \mathrm{mg}$, the total initial DB9 concentration $25 \mathrm{mg} / \mathrm{L}$, and the contact time was 180 minutes at $298 \mathrm{~K}$. The results are given

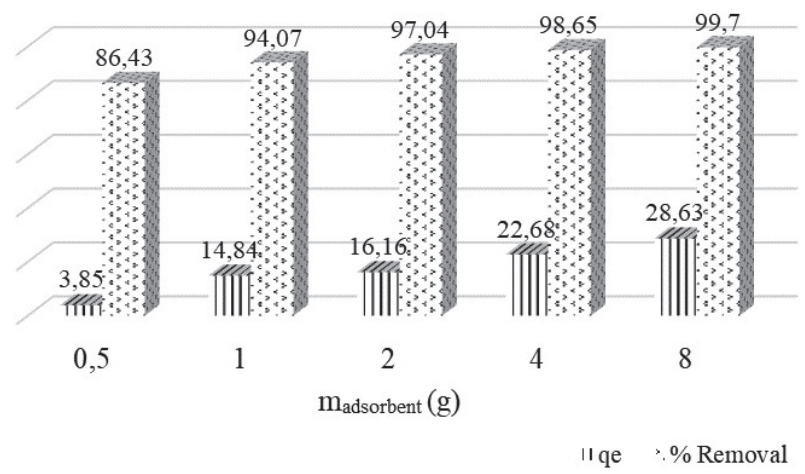

Fig. 7. Effect of adsorbent dosage for adsorption capacity $\left(q_{e}\right)$ and percentage removal $(\% R)$ of DB9 onto poly(HEMA).

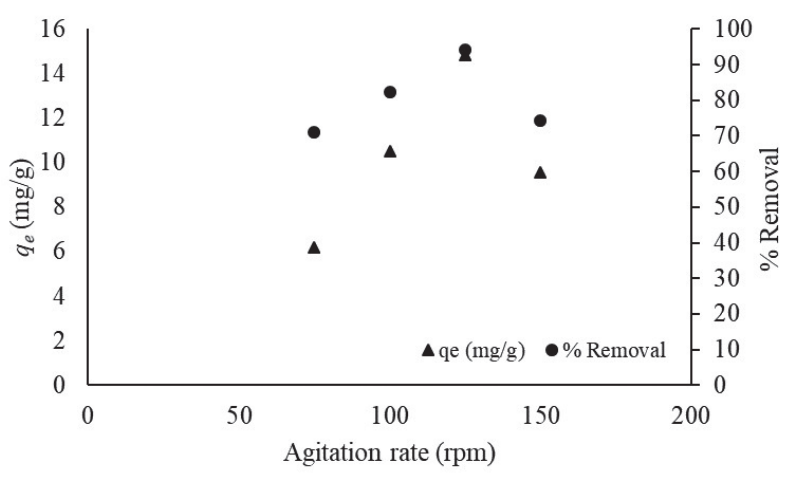

Fig. 8. Effect of agitation rate for adsorption capacity $\left(q_{e}\right)$ and percentage removal $(\% R)$ of DB9 onto poly(HEMA).

in Fig. 8. The maximum removal of DB9 occurred at $125 \mathrm{rpm}$. Agitation of solution helps for better interaction between binding sites of both adsorbent and dye molecules, so these molecules penetrate to deeper layers of the adsorbent. When the agitation rate exceeded the optimum speed, the interaction between adsorbent and dye molecules decreased [46].

\section{Adsorption Isotherms}

The adsorption capacity and other parameters were evaluated using Langmuir, Freundlich and Sips isotherm models. The adsorption capacity $\left(q_{e}\right)$ was determined as $16.24 \mathrm{mg} / \mathrm{g}$ (Table 1). The high value of correlation coefficient $(0.987)$ point at the practicality of Langmuir isotherm which supposes uniform activity distribution and a monolayer coverage on the sorbent surface. $R_{L}$ values also support the adsorption of dye onto poly(HEMA) (Table 1).

The equilibrium data were also fitted to the Freundlich isotherm model. The parameters $K_{F}$ and $n$ are 0.226 and 1.392 , respectively. $1 / n$ gives an indication of the suitability of the sorbent/adsorbate systems [47].

\section{Adsorption Thermodynamics}

Thermodynamic parameters such as free energy change $(\Delta G)$, enthalpy changes $(\Delta H)$ and entropy changes $(\Delta S)$ were calculated using the Van't Hoff equation at various temperatures [48] (Eq. 6):

$$
\ln K_{L}=-\frac{\Delta H^{0}}{R T}+\frac{\Delta S^{0}}{R}
$$

...where $K_{L}$ is the Langmuir equilibrium constant, $T$ is the absolute temperature $(\mathrm{K})$ and $R$ is the universal gas constant $(8.314 \mathrm{~J} / \mathrm{mol} \mathrm{K}) \cdot \Delta \mathrm{H}^{0}$ and $\Delta \mathrm{S}^{0}$ can be determined from the slope and intercept of the plot of $\ln$ $K_{L}$ versus $1 / T$. The $\Delta \mathrm{G}^{0}$ of the adsorption was calculated using Eq. 7:

$$
\Delta G^{0}=\Delta H^{0}-T \Delta S^{0}
$$


Table 1. Adsorption isotherm models for DB9 adsorption onto poly(HEMA).

\begin{tabular}{|c|c|c|c|c|c|c|c|c|c|}
\hline & \multicolumn{3}{|c|}{ Langmuir Isotherm Model } & \multicolumn{3}{c|}{ Freundlich Isotherm Model } & \multicolumn{3}{c|}{ Sips Isotherm Model } \\
\hline $\begin{array}{c}\text { Temperature } \\
(\mathrm{K})\end{array}$ & $\begin{array}{c}K_{L} \times 10^{2}(\mathrm{~L} / \\
\mathrm{mg})\end{array}$ & $Q_{L}(\mathrm{mg} / \mathrm{g})$ & $\mathrm{R}^{2}$ & $\begin{array}{c}K_{F}(\mathrm{~L} / \\
\mathrm{mg})\end{array}$ & $n$ & $\mathrm{R}^{2}$ & $\begin{array}{c}K_{S} \times 10^{2} \\
(\mathrm{~L} / \mathrm{mg})\end{array}$ & $\begin{array}{c}Q_{\max } \\
(\mathrm{mg} / \mathrm{g})\end{array}$ & $\mathrm{R}^{2}$ \\
\hline 298 & 4.68 & 16.24 & 0.987 & 0.226 & 1.392 & 0.928 & 11.54 & 0.575 & 0.954 \\
\hline
\end{tabular}

Table 2. Thermodynamic parameters for DB9 adsorption onto poly(HEMA).

\begin{tabular}{|c|c|c|c|}
\hline $\mathrm{T}(\mathrm{K})$ & $\Delta G^{o}(\mathrm{~kJ} / \mathrm{mol})$ & $\Delta H^{o}(\mathrm{~kJ} / \mathrm{mol})$ & $\Delta S^{o}(\mathrm{~J} / \mathrm{mol} . \mathrm{K})$ \\
\cline { 1 - 2 } 277 & -1.716 & & \\
\cline { 1 - 2 } 298 & -2.018 & \multirow{2}{*}{2.276} & 14.412 \\
\cline { 1 - 2 } 318 & -2.307 & & \\
\hline
\end{tabular}

The data are listed in Table 2. The positive $\Delta \mathrm{H}^{0}$ depicted that the dye adsorption on polymeric adsorbent was endothermic. The negative $\Delta \mathrm{G}^{0}$ indicates that the adsorption process occurs spontaneously. Besides the positive value of entropy change, $\left(\Delta S^{0}\right)$ defines the affinity of adsorbent for the dye.

\section{Adsorption Kinetics}

Adsorption kinetics is one of the important parameters for investigating the mechanism of adsorption [49]. In this study, pseudo first-order, pseudo second-order, and intraparticle diffusion kinetic models were used to clarify the adsorption kinetics.

The pseudo first- and second-order kinetic models are expressed at Eq. 8 and Eq. 9, respectively:

$$
\begin{gathered}
\ln \left(q_{e}-q_{t}\right)=\ln q_{e}-k_{1} t \\
\frac{t}{q_{t}}=\frac{1}{k_{2} q_{e}^{2}}+\frac{t}{q_{e}}
\end{gathered}
$$

...where $q_{e}$ is the amount of dye adsorbed by polymer at equilibrium condition $(\mathrm{mg} / \mathrm{g}), q_{t}$ is the amount of dye adsorbed by polymer at time $t$ ( $\mathrm{min})$, and $k_{l}(1 / \mathrm{min})$ and $k_{2}(\mathrm{~g} / \mathrm{mg} \mathrm{min})$ are the equilibrium rate constants for pseudo first- and second-order kinetic models, respectively. For the pseudo first-order kinetic model, $k_{1}$ and $q_{e}$ are obtained from the slope and intercept of the plot of $\ln \left(q_{e}-q_{t}\right)$ versus $t$, respectively [50]. For the pseudo second-order kinetic model, $k_{2}$ and $q_{e}$ are determined from the slope and intercept of the plot of $t / q_{t}$ versus $t$, respectively [51, 52].

The intraparticle diffusion model explains that the adsorption process occurs in several steps involving the transport of solute molecules from bulk aqueous phase to the surface of the adsorbent particles, which is followed by diffusion of the molecules into the interior of the solid pores [43, 51]. For most adsorption processes, the amount of adsorption is commensurate to $\mathrm{t}^{1 / 2}$ rather than with the contact time. This model can be expressed at Eq. 10:

$$
q_{t}=k_{i d} t^{1 / 2}
$$

...where $q_{t}$ is the adsorption capacity at time $t(\mathrm{~min}), t^{1 / 2}$ is the half-life time in second and $k_{i d}$ is the intraparticle diffusion rate constant $\left(\mathrm{mg} / \mathrm{g} \mathrm{min}^{1 / 2}\right)$ at different initial dye concentrations. $k_{i d}$ can be calculated from the slope of the plot. The adsorption kinetic models and parameters are given in Table 3.

According to the results, the best-fit kinetic model can be chosen dependent upon the linear regression correlation coefficient $\left(\mathrm{R}^{2}\right)$ values. Furthermore, $q_{e}$ values are closed to experimental $q_{e}$ values in the pseudo second-order kinetic model. Usually for most adsorption systems, the pseudo second-order kinetic model is better and well represented [51]. For removing textile dyes from aqueous solutions a great number of adsorbents such as ash, polymeric particles or microbial biomass can be used effectively. Adsorption capacities of various adsorbents for different kinds of dyes are given in Table 4.

\section{Recyclability of the Adsorbent}

One of the important parameters in adsorption-based

\begin{tabular}{|c|c|c|c|c|c|c|c|c|c|}
\hline \multirow{2}{*}{$\begin{array}{c}\text { Parameters } \\
\text { Temperature } \\
\text { (K) }\end{array}$} & \multirow{2}{*}{$\begin{array}{l}\text { Experimental } \\
\mathrm{q}_{\mathrm{e}}(\mathrm{mg} / \mathrm{g})\end{array}$} & \multicolumn{3}{|c|}{$\begin{array}{l}\text { Pseudo-first order } \\
\text { kinetic model }\end{array}$} & \multicolumn{3}{|c|}{$\begin{array}{l}\text { Pseudo-second order } \\
\text { kinetic model }\end{array}$} & \multicolumn{2}{|c|}{$\begin{array}{c}\text { Intraparticle diffusion } \\
\text { model }\end{array}$} \\
\hline & & $\begin{array}{l}k_{1} \times 10^{2} \\
(1 / \mathrm{min})\end{array}$ & $q_{e}(\mathrm{mg} / \mathrm{g})$ & $R^{2}$ & $\begin{array}{c}\mathrm{k}_{2} \times 10^{2} \\
((\mathrm{~g} / \mathrm{mg}) / \mathrm{min})\end{array}$ & $q_{e}(\mathrm{mg} / \mathrm{g})$ & $\mathrm{R}^{2}$ & $k_{i d}$ & $\mathrm{R}^{2}$ \\
\hline 277 & 12.983 & 2.62 & 2.188 & 0.9865 & 7.01 & 11.87 & 0.9981 & 0.68 & 0.8908 \\
\hline 298 & 14.841 & 4.67 & 3.0436 & 0.9671 & 5.68 & 15.24 & 0.9922 & 1.02 & 0.8522 \\
\hline 318 & 15.486 & 3.65 & 3.0243 & 0.9547 & 5.19 & 18.59 & 0.9663 & 1.09 & 0.8315 \\
\hline
\end{tabular}
processes is desorption and reusability of the adsorbent.

Table 3. Adsorption kinetic models and parameters for removal of DB9 onto poly(HEMA). 
Table 4. Adsorption capacities of various adsorbents for different kinds of dyes.

\begin{tabular}{|c|c|c|c|c|}
\hline Adsobent & Dye & $q_{e}$ & $\% R$ & Reference \\
\hline KT3B kaolin & MB & $52.76 \mathrm{mg} / \mathrm{g}$ & - & 52 \\
\hline Trimellitated-sugarcane bagasse & $\begin{array}{l}\text { Auramine-O } \\
\text { Safranin-T }\end{array}$ & $\begin{array}{l}1.005 \mathrm{mmol} / \mathrm{g} \\
0.638 \mathrm{mmol} / \mathrm{g}\end{array}$ & $\begin{array}{l}- \\
-\end{array}$ & 53 \\
\hline Chitosan-based composite hydrogel & Rhodamine $6 \mathrm{G}$ & - & 87.31 & 54 \\
\hline Coal fly ash & Indigo carmine & $1.48 \mathrm{mg} / \mathrm{g}$ & - & 55 \\
\hline Calcium hydroxide & Indigo carmine & $0.95 \mathrm{mg} / \mathrm{g}$ & - & 56 \\
\hline $\begin{array}{l}\text { Activated carbon-entrapped microfibrilated cellulose } \\
\text { film }\end{array}$ & brilliant red 5GN & $19.30 \mathrm{mg} / \mathrm{g}$ & - & 57 \\
\hline $\mathrm{Ni} / \mathrm{C}$ nanoparticles & $\begin{array}{l}\text { Rhodamine B } \\
\text { Methylene Blue }\end{array}$ & $\begin{array}{l}3.935 \mathrm{mg} / \mathrm{g} \\
5.204 \mathrm{mg} / \mathrm{g}\end{array}$ & - & 58 \\
\hline poly (N-isopropylacrylamide)-co-acrylic acid microgel & Orange II & - & $\% 29.5$ & 59 \\
\hline poly HEMA-chitosan-MWCNT nano-composite & Methyle orange & $306 \mathrm{mg} / \mathrm{g}$ & - & 60 \\
\hline Lyophilized Trametes versicolor biomass & Sirius Blue K-FCN & $62.62 \mathrm{mg} / \mathrm{g}$ & - & 42 \\
\hline Poly(HEMA) nanoparticles & Direct Blue 9 & $15.49 \mathrm{mg} / \mathrm{g}$ & $98.15 \%$ & This study \\
\hline
\end{tabular}

It is required that the desorption agent does not damage the adsorbent or affect adsorption capacity. In this study, the recyclability experiment of DB9 was carried out. Sodium acetate buffer was used as a desorption agent in the recyclability studies. The DB9 adsorbed polymers were shaken at room temperature for $3 \mathrm{~h}$. It was found that during a 5 adsorption-desorption cycle the adsorption capacity of the nanopolymer decreased only $5.5 \%$.

\section{Conclusions}

In this study, poly(HEMA) nanopolymers were produced, characterized and investigated regarding their abilities to remove textile dye Direct Blue 9 (DB9) in aqueous solution for the first time. The optimum $\mathrm{pH}$ and temperature for adsorption of DB9 from aqueous solution were determined as 6.0 and $318 \mathrm{~K}$, respectively. All experiments were achieved at $\mathrm{pH}$ 6.0. Increasing the temperature from $277 \mathrm{~K}$ to $318 \mathrm{~K}$, the maximum adsorption capacity was also increased from $12.98 \mathrm{mg} / \mathrm{g}$ to $15.49 \mathrm{mg} / \mathrm{g}$ and percentage removal of DB9 from $82.30 \%$ to $98.15 \%$, respectively. Results obtained indicate that the adsorption process is fast and spontaneous within the first $90 \mathrm{~min}$. Isotherm, thermodynamic and kinetic studies were performed to clarify the nature of the adsorption process. The experimental data supports the pseudo secondorder model. The adsorption process is fitted to the Langmuir isotherm model. In addition, the mean values of thermodynamic parameters of standard free energy, standard enthalpy $\left(\Delta H^{0}=2.276 \mathrm{~kJ} \mathrm{~mol}^{-1}\right)$ and standard entropy $\left(\Delta S^{0}=14.412 \mathrm{~J} \mathrm{~mol}^{-1} \mathrm{~K}^{-1}\right)$ of the adsorption mechanism were determined. In conclusion, poly(HEMA) was examined as an adsorbent for the adsorption of a textile dye, Direct Blue 9, in aqueous solutions at the first time and reported the suitability of the poly(HEMA) as an adsorbent.

\section{Acknowledgements}

This study was performed at the Department of Biochemistry Faculty of Science Ege University, Izmir, Turkey. Special thanks to Prof. Dr. Nurdan Kaşıkara Pazarlıoğlu, Assistant Prof. Alper Akkaya and Dr. Emre Erden.

\section{Conflict of Interest}

The authors declare no conflict of interest.

\section{References}

1. KADAM A.A., LEE D.S. Glutaraldehyde crosslinked magnetic chitosan nanocomposites: Reduction precipitation synthesis, characterization, and application for removal of hazardous textile dyes. Biosour. Technol. 193, 563, 2015.

2. ELMOUBARKI R., MAHJOUBI F.Z., TOUNSADI H., MOUSTADRAF J., ABDENNOURI M., ZOUHRI A., EL ALBANI A., BARKA N. Adsorption of textile dyes on raw and decanted Moroccan clays: Kinetics, equilibrium and thermodynamics. Water Resources and Industry. 9, 16, 2015.

3. BANERJEE S., CHATTOPADHYAYA M.C. Adsorption characteristics for the removal of a toxic dye, tartrazine from aqueous solutions by a low-cost agricultural byproduct. Arab. J. Chem. 10, S1629, 2017.

4. SHAJAHAN A., SHANKAR S., SATHIYASEELAN A., NARAYAN K.S., NARAYANAN V., KAVIYARASAN 
V., IGNACIMUTHU S. Comparative studies of chitosan and its nanoparticles for the adsorption efficiency of various dyes. Int. J. Biol. Macromol. 104, 1449, 2017.

5. HUANG R., LIU Q., HUO J., YANG B. Adsorption of methyl orange onto protonated crosslinked chitosan. Arab. J. Chem. 10, 24, 2017.

6. SUBRAMANI S.E., THINAKARAN N. Isotherm, Kinetic and thermodynamic studies on the adsorption behaviour of textile dyes onto chitosan. Process Saf. Environ. 106, 1, 2017.

7. YANG R., LI H., HUANG M., YANG H., LI A. A review on chitosan-based flocculants and their applications in water treatment. Water Res. 95, 59, 2016.

8. DAO V.H., CAMERON N.R., SAITO K. Synthesis, properties and performance of organic polymers employed in flocculation applications. Polym. Chem. 7 (1), 11, 2016.

9. DOTTO J., VEIT M.T., MORENO PALACIO S., BERGAMASCO R. Performance of different coagulants in the coagulation/flocculation process of textile wastewater. J. Clean. Prod. 208, 656, 2019.

10. FANE A.G., WANG R., HU M.X. Synthetic membranes for water purification: status and future. Angew. Chem. Int. Ed. 54 (11), 3368, 2015.

11. PEYDAYESH M. MOHAMMADI T., BAKHTIARI O. Effective treatment of dye wastewater via positively charged TETA-MWCNT/PES hybrid nanofiltration membranes. Sep. Purif. Technol. 194, 488, 2018.

12. EL-ASHTOUKHY E.-S. Z., AMIN N. K., ABD EL-LATIF M.M., BASSYOUNI D.G. HAMAD H.A. New insights into the anodic oxidation and electrocoagulation using a self-gas stirred reactor: a comparative study for synthetic C.I Reactive Violet 2 wastewater. J. Clean. Prod. 167, 432, 2017.

13. BASSYOUNI D.G., HAMAD H.A., EL-ASHTOUKHY E.-S.Z., AMIN N.K., ABD EL-LATIF M.M. Comparative performance of anodic oxidation and electrocoagulation as clean processes for electrocatalytic degradation of diazo dye Acid Brown 14 in aqueous medium. J. Hazard. Mater. 335, 178, 2017.

14. SPASIANO D., SICILIANO A., RACE M., MAROTTA R., GUIDA M., ANDREOZZI R., PIROZZI F. Biodegradation, ecotoxicity and $\mathrm{UV}_{254} / \mathrm{H}_{2} \mathrm{O}_{2}$ treatment of imidazole, 1-methyl-imidazole and $\mathrm{N}, \mathrm{N}^{\prime}$-alkyl-imidazolium chlorides in water. Water Res., 106, 450, 2016.

15. HAMAD H.A., ABD EL-LATIF M.M., KASHYOUT A.B., SADIK W.A., FETEHA M.Y. Optimizing the preparation parameters of mesoporous nanocrystalline titania and its photocatalytic activity in water: physical properties and growth mechanisms. Process Saf. Environ. Prot. 98, 390, 2015.

16. HAMAD H.A., SADIK W.A., ABD EL-LATIF M.M., KASHYOUT A.B., FETEHA M.Y. Photocatalytic parameters and kinetic study for degradation of dichlorophenol-indophenol (DCPIP) dye using highly active mesoporous $\mathrm{TiO}_{2}$ nanoparticles. J. Environ. Sci. 43, 26, 2016.

17. ELKADY M., SHOKRY H., HAMAD H. Effect of superparamagnetic nanoparticles on the physicochemical properties of nano hydroxyapatite for groundwater treatment: adsorption mechanism of $\mathrm{Fe}(\mathrm{II})$ and $\mathrm{Mn}(\mathrm{II})$. RSC Adv. 6, 82244, 2016.

18. ZHAO S.-N., KRISHNARAJ C., JENA H. J., POELMAN D., VAN DER VOORT P. An anionic metal-organic framework as a platform for charge-and size-dependent selective removal of cationic dyes. Dyes Pigments. 156, 332, 2018.
19. EL ESSAWY N.A., ALI S.M., FARAG H.A., KONSOWA A.K., ELNOUBY M., HAMAD H.A. Green synthesis of graphene from recycled PET bottle wastes for use in the adsorption of dyes in aqueous solution. Ecotox. Environ. Saf. 145, 57, 2017.

20. MURRAY A., OMERCI B. Competitive effects of humic acid and wastewater on adsorption of Methylene Blue dye by activated carbon and non-imprinted polymers. J. Environ Sci. 66, 310, 2018.

21. HAMAD H., BASSYOUNI D., EL-ASHTOUKHY E.-S., AMIN N., ABD EL-LATIF M. Electrocatalytic degradation and minimization of specific energy consumption of synthetic azo dye from wastewater by anodic oxidation process with an emphasis on enhancing economic efficiency and reaction mechanism. Ecotox. Environ. Safe. 148, 501, 2018.

22. MONTE BLANCO S.P.D., SCHEUFELE F.B., MÓDENES A.N., ESPINOZA-QUIÑONES F.R., MARIN P., KROUMOV A.D., BORBA C.E. Kinetic, equilibrium and thermodynamic phenomenological modeling of reactive dye adsorption onto polymeric adsorbent. Chem. Eng. J. 307, 466, 2017.

23. PATHANIA D., SHARMA S., SINGH P. Removal of methylene blue by adsorption onto activated carbon developed from Ficus carica bast., Arab. J. Chem. 10, 1445, 2017.

24. TANG Y., YANG R., MA D., ZHOU B., ZHU L., YANG J. Removal of methyl orange from aqueous solution by adsorption onto a hydrogel composite. Polym. Polym. Compos. 26 (2), 161, 2018.

25. TORGUT G., DEMIRELLI K. Comparative adsorption of different dyes from aqueous solutions onto polymer prepared by rop: kinetic, equilibrium and thermodynamic studies. Arab. J. Sci. Eng. 43, 3503, 2018.

26. PAVAS E.G., DOBROSZ-GOMEZ I., GOMEZ-GARCIA M.-A., Optimization and toxicity assessment of a combined electrocoagulation, $\mathrm{H}_{2} \mathrm{O}_{2} / \mathrm{Fe}^{2+} / \mathrm{UV}$ and activated carbon adsorption for textile wastewater treatment. Sci. Total Environ. 651 (1), 551, 2019.

27. DERYLO-MARCZEWSKA A., BLACHNIO M., MARCZEWSKI A. W., SECZKOWSKA M., TARASIUK B. Phenoxyacid pesticide adsorption on activated carbon - Equilibrium and kinetics. Chemosphere. 214, 349, 2019.

28. AFROZE S., SEN T.K. A Review on Heavy Metal Ions and Dye Adsorption from Water by Agricultural Solid Waste Adsorbents. Water Air Soil Pollut. 229 (7), 225, 2018.

29. BAYSAL M., BILGE K., YILMAZ B., PAPILA M., YURUM Y. Preparation of high surface area activated carbon from waste-biomass of sunflower piths: Kinetics and equilibrium studies on the dye removal, J. Environ Chem. Eng. 6 (2), 1702, 2018.

30. CHAARI I., FAKHFAKH E., MEDHIOUB M., JAMOUSSI F. Comparative study on adsorption of cationic and anionic dyes by smectite rich natural clays. J. Mol. Struct. 1179, 672, 2019.

31. LIU S., CHEN X., AI W., WEI C. A new method to prepare mesoporous silica from coal gasification fine slag and its application in methylene blue adsorption. J. Clean. Prod. 212, 1062, 2019.

32. SHABAN M., ABUKHADRA M.R., SHAHIEN M.G., IBRAHIM S.S. Novel bentonite/zeolite-NaP composite efficiently removes methylene blue and Congo red dye. Environ. Chem. Lett. 16, 275, 2018.

33. MAHMOODI M.N., SAFFAR-DASTGERDI M.H. Zeolite nanoparticle as a superior adsorbent with high capacity: 
Synthesis, surface modification and pollutant adsorption ability from wastewater. Microchem. J. 145, 74, 2019.

34. JAIN S.N., GOGATE P.R. Efficient removal of Acid Green 25 dye from wastewater using activated Prunus Dulcis as biosorbent: Batch and column studies, J. Environ. Manage. 210, 226, 2018.

35. ROY U., MANNA S., SENGUPTA S., DAS P., DATTA S., MUKHOPADHYAY A., BHOWAL A. Dye Removal Using Microbial Biosorbents, Green Adsorbents for Pollutant Removal. 2018.

36. RANGABHASHIYAM S., SUJATA L., BALASUBRAMANIAN P. Biosorption characteristics of methylene blue and malachite green from simulated wastewater onto Carica papaya wood biosorbent. Surf. Interface. 10, 197, 2018.

37. SAMADI N., HASANZADEH R., RASAD M. Adsorption isotherms, kinetic, and desorption studies on removal of toxic metal ions from aqueous solutions by polymeric adsorbent. J. Appl. Polym. Sci. 416422015.

38. GÖÇENOĞLU SARIKAYA A. Removal of diazo-dye Direct Blue 2 (DB2) in aqueous solution by P(HEMA) nanoparticles. J. BAUN Inst. Sci. Technol. 21 (1), 278, 2019.

39. MOGHADDAM S.S., MOGHADDAM M.R., ARAMI M. Coagulation/flocculation process for dye removal using sludge from water treatment plant: Optimization through response surface methodology. J. Hazard. Mater. 175 (1-3), 651, 2010.

40. LANGMUIR I. The adsorption of gases on plane surfaces of glass, mica and platinum. JACS. 40, 1361, 1918.

41. FREUNDLICH H. Over the adsorption in solution. J. Phys. Chem. 57, 385, 1906.

42. ERDEN E., KAYMAZ Y., KASIKARA PAZARLIOGLU N. Biosorption kinetics of a direct azo dye Sirius Blue $\mathrm{K}-\mathrm{CFN}$ by Trametes versicolor. Electron. J. Biotechn. 14 (2), 1, 2011.

43. BENSALAH H., BEKHEET M.F., YOUNSSI S.A., OUAMMOU M., GURLO A., Removal of cationic and anionic textile dyes with Moroccan natural phosphate. J. Environ. Chem. Eng. 5, 2189, 2017.

44. MAHMOUD M.E., NABIL G.M., EL-MALLAH N.M., BASSIOUNY H.I., KUMAR S., ABDEL-FATTAH T.M., Kinetics, isotherm, and thermodynamic studies of the adsorption of reactive red 195 a dye from water by modified switchgrass biochar adsorbent. J. Ind. Eng. Chem. 37, 156, 2016.

45. SALLEH M.A.M. MAHMOUD D.K., KARIM W.A.W.A., IDRIS A. Cationic and anionic dye adsorption by agricultural solid wastes: A comprehensive review. Desalination. 280 (1), 1, 2011.

46. ACHAK M., HAFIDIB A., OUAZZANIA N., SAYADIC S., MANDIA L. Low cost biosorbent "banana peel" for the removal of phenolic compounds from olive mill wastewater: Kinetic and equilibrium studies. J. Hazar. Mater. 166, 117, 2009.

47. TAHIR M.A., BHATTI H.N., IQBAL M. Solar Red and Brittle Blue direct dyes adsorption onto Eucalyptus angophoroides bark: Equilibrium, kinetics and thermodynamic studies. J. Environ. Chem. Eng. 4, 2431, 2016.
48. AL-DEGS Y.S., EL-BARGHOUTHI M.I., ISSA A.A., KHRAISHEH M.A., WALKER G.M. Sorption of Zn(II), $\mathrm{Pb}$ (II), and $\mathrm{Co}(\mathrm{II})$ using natural sorbents: Equilibrium and kinetic studies. Water Res. 40 (14), 2645, 2006.

49. CHEN L., BAI B. Equilibrium, kinetic, thermodynamic, and in situ regeneration studies about Methylene Blue adsorption by the raspberry-like $\mathrm{TiO}_{2}$-yeast microspheres. Ind. Eng. Chem. Res. 52, 15568, 2013.

50. SHENVI S.S., ISLOOR A.M., ISMAIL A.F., SHILTON S.J., AL AHMED A. Humic acid based biopolymeric membrane for effective removal of Methylene Blue and Rhodamine B. Ind. Eng. Chem. Res. 54 (18), 4965, 2015.

51. YAGUB M.T., SEN T.K., AFROZE S., ANG H.M. Dye and its removal from aqueous solution by adsorption: A review. Adv. Colloid Interfac. 209, 172, 2014.

52. MOUNI L., BELKHIRI L., BOLLINGER J.C., BOUZAZA A., ASSADI A., TIRRI A., DAHMOUNE F., MADANI K., REMINI H. Removal of Methylene Blue from aqueous solutions by adsorption on kaolin: Kinetic and equilibrium studies. Appl. Clay Sci. 153 (1), 38, 2018.

53. APARECIDA FIDELES R., DIAS FERREIRA G.M., TEODORO F.S., HERRERA ADARME O.F., MENDESDA SILVA L.H., GIL L.F., ALVES GURGEL L.V. Trimellitated sugarcane bagasse: A versatile adsorbent for removal of cationic dyes from aqueous solution. Part I: Batch adsorption in a monocomponent system J. Colloid. Interf. Sci. 515, 172, 2018.

54. BHULLAR N., KUMARI K., SUD D. A biopolymerbased composite hydrogel for rhodamine $6 \mathrm{G}$ dye removal: its synthesis, adsorption isotherms and kinetics. Iran. Polym. J. 27 (7), 527, 2018.

55. de CARVALHO T.E., FUNGARO D.A., MAGDALENA C.P., CUNICO P. Adsorption of indigo carmine from aqueous solution using coal fly ash and zeolite from fly ash. J. Radioanal. Nucl. Chem. 289, 617, 2011.

56. RAMESH T.N., KIRANA D.V., ASHWINI A., MANASA T. Calcium hydroxide as low cost adsorbent for the effective removal of indigo carmine dye in water. J. Saudi. Chem. Soc. 21, 165, 2015.

57. PEI Y., WU X., XU G., CHEN M., ZHANG Z., ZHENG X., LIU J., TANG K. Activated carbon-entrapped microfibrilated cellulose films as an effective adsorbent for removing organic dye from aqueous effluent, J. Wood Chem. Technol. 38 (1), 15, 2018.

58. KIM T.S., SONG H.J., DAR M.A., LEE H.J., KIM D.W. Fast adsorption kinetics of highly dispersed ultrafine nickel/carbon nanoparticles for organic dye removal. Appl. Surf. Sci. 439, 364, 2018.

59. PARASURAMAN D., SERPE DEEPIKA M.J. Poly (N-Isopropylacrylamide) microgels for organic dye removal from water. ACS Appl. Mater. Interfaces. 3, 2732, 2011.

60. MAHMOODIAN H., MORADI O., SHARIATZADEHA B., SALEHF T.A., TYAGI I., MAITY A., VINOD V. A., GUPTA K. Enhanced removal of methyl orange from aqueous solutions by poly HEMA-chitosan-MWCNT nano-composite J. Mol. Liq. 202, 189, 2015. 
